\title{
sciendo
}

\section{DIETARY SILYMARIN, SILYBUM MARIANUM EXTRACT AMELIORATES CADMIUM CHLORIDE TOXICITY IN COMMON CARP, CYPRINUS CARPIO}

\author{
Sarmad Ghazi Al-Shawi ${ }^{1}$, Asraa Yacoob Yousif ${ }^{2}$, Zena Kadhim Al-Younis ${ }^{3}$, Rustem Adamovich Shichiyakh ${ }^{4}$, Angelina Olegovna Zekiy $^{5}$, \\ Saeid Shahbazi Naserabad ${ }^{6 \star}$
}

\author{
${ }^{1}$ Food Science Department, Agriculture College, Basrah University, Basrah 00964, Iraq \\ ${ }^{2}$ Animal Production Department, Agriculture College, Basrah University, Basrah 00964, Iraq \\ ${ }^{3}$ Food Science Department, Agriculture College, Basrah University, Basrah 00964, Iraq \\ ${ }^{4}$ Department of Management, Kuban State Agrarian University named after I.T. Trubilin, \\ 13 Kalinina Street, 350044, Krasnodar, Russia \\ ${ }^{5}$ Department of Prosthetic Dentistry, Sechenov First Moscow State Medical University, Moscow, Russia \\ ${ }^{6}$ Department of Fisheries, Faculty of Natural Resources, University of Tehran, Karaj, Iran \\ •Corresponding author: saeid.shahbazi@alumni.ut.ac.ir
}

\begin{abstract}
The present study evaluated the protective effects of silymarin extract (SIE) on cadmium chloride toxicity in common carp, Cyprinus carpio. Four experimental groups were considered for the experiment including: SIE $_{0}$ (control): non-SIE-supplemented fish, SIE $_{1}$ : fish supplemented with $400 \mathrm{mg} \mathrm{SIE} / \mathrm{kg}$ diet, $\mathrm{SIE}_{2}$ : fish supplemented with $1400 \mathrm{mg} \mathrm{SIE} / \mathrm{kg}$ diet, $\mathrm{SIE}_{3}$ : fish supplemented with $2400 \mathrm{mg}$ SIE/ $\mathrm{kg}$ diet. Fish were fed experimental diet for 60 days and then exposed to cadmium chloride (1.5 mg/l or $25 \%$ of LC50-96 h) and antioxidant defense components and the survival rate assayed. After 60 days feeding trial, total antioxidant capacity (TAC) levels significantly increased $(\mathrm{P}<0.01)$ in 1400-2400 $\mathrm{mg} \mathrm{SIE} / \mathrm{kg}$ diet treatments compared to those in control and $400 \mathrm{mg} \mathrm{SIE} / \mathrm{kg}$ diet treatment. Malondialdehyde (MDA) $(\mathrm{P}>0.01)$ and acetylcholinesterase $(\mathrm{AChE})$ levels $(\mathrm{P}>0.01)$ remained unchanged during the feeding period in all treatments. Hepatic catalase (CAT) in all SIE supplemented groups and superoxide dismutase (SOD) and glutathione peroxidase (GPx) in 1400-2400 $\mathrm{mg} \mathrm{SIE} / \mathbf{k g}$ diet treatments significantly elevated $(\mathrm{P}<\mathbf{0 . 0 1})$ in response to SIE. Plasma levels of hepatic metabolic enzymes [alanine transaminase (ALT), aspartate aminotransferase (AST), alkaline phosphatase (ALP), creatine kinase (CK), lactate dehydrogenase $(\mathrm{LDH})]$ remained unchanged $(\mathrm{P}>\mathbf{0 . 0 1})$ in all experimental groups over feeding period. After exposure to cadmium chloride, TAC levels were significantly elevated $(\mathrm{P}<0.01)$ in all experimental groups. In control and $400 \mathrm{mg} \mathrm{SIE} / \mathrm{kg}$ diet treatment, TAC showed lower levels $(P<0.01)$ compared to other groups. MDA levels were significantly increased $(P<0.01)$ in control and fish supplemented with 400 and 1400 $\mathrm{mg} \mathrm{SIE} / \mathrm{kg}$ diet. TAC in the fish of $2400 \mathrm{mg} \mathrm{SIE} / \mathrm{kg}$ diet treatment remained unchanged $(\mathrm{P}>0.01)$, following the exposure. CAT $(\mathrm{P}<0.01)$, SOD $(P<0.01)$ and GPx $(P<0.01)$ were significantly elevated in response to cadmium chloride in all groups. However, the treatments, 1400 and $2400 \mathrm{mg} \mathrm{SIE} / \mathrm{kg}$ diet, showed lower increases $(\mathrm{P}<0.01)$ of enzymes. $\mathrm{AChE}$ activity $(\mathrm{P}<0.01)$ in the liver were significantly decreased in control and fish fed 400 and $1400 \mathrm{mg}$ SIE/kg diet. Exposure to cadmium significantly increased $(P<0.01)$ the plasma levels of ALT, AST, ALP and LDH in control and those fed 400 and $1400 \mathrm{mg} \mathrm{SIE} / \mathrm{kg}$ diet. The findings of the current study indicated that SIE at a rate of $1400-2400 \mathrm{mg} / \mathrm{kg}$ diet might enhance antioxidant defense and protect hepatocytes against toxic effects of cadmium.
\end{abstract}

Key words: heavy metal, liver, blood, herbal extract, fish

Contamination of aquatic ecosystems with heavy metals and their effects on aquatic organisms has been the subject of many studies (Ansari et al., 2004; Bhuyan and Islam, 2017; Sodango et al., 2018; Joksimović et al., 2020; Hajirezaee et al., 2021). Heavy metals usually enter aquatic environments through effluents from industrial and agricultural activities (Tahar and Keltoum, 2011; Miskowiec et al., 2015; Yang et al., 2018).

In fish, it has been recognized that heavy metal toxicity could alter all aspects of life such as growth, reproduction, osmoregulation, and immunity (Ebrahimi and Taherianfard, 2011; Saglam et al., 2013; Guardiola et al., 2015; Jinhui et al., 2019). Therefore, finding efficient ways to reduce the harmful effects of heavy metals on aquatic organisms would be of great importance. As a natural way, few studies indicate that herbal sup- plements and their derivatives can mitigate the negative physiological effects of contaminants in fish (Hajirezaee et al., 2019; Rafieepour et al., 2019 a, b; Ahmadifar et al., 2020; Elumalai et al., 2020; Mohammed et al., 2020; Dawood et al., 2020; Khafaga et al., 2020; Zhu, 2020; Ahmadifar et al., 2021). As a medicinal plant, the therapeutic properties of the milk thistle, Silybum mariamum have been well recognized for many years (Křen and Walterová, 2005). Silymarin is a polyphenolic compound extracted from Silybum mariamum with strong antioxidant activity (Kvasnička et al., 2003). Banaee et al. (2015 a) used silymarin extracts to moderate the toxicity of malathion in zebrafish and Cichlasoma nigrofasciatum. They reported that the protective effects of silymarin are probably exerted through enhancing the hepatic antioxidant capacity and hepatic enzymes. Nazdar et al. (2018) 
demonstrated the protecting effects of silymarin on pancreatic tissue and digestive capacity of rainbow trout exposed to nickel oxide nanoparticles. As a medicinal plant, dietary S. marianum enhanced some non-specific immune responses in C. carpio (Alishahi et al., 2011). The oxidative stress induced by heavy metals causes a wide spectrum of physiological and histological lesions in fish (Chowdhury and Saikia, 2020). In toxicological studies, biochemical changes in the liver and blood are usually used to evaluate the mode of action of toxicants (Chupani et al., 2017, 2018). Plasmatic and hepatic enzymes were a good reflection of environmental stressors and provide a comprehensive view on the status of immunity (Yousafzai and Shakoori, 2011). In this research, we have studied the effects of silymarin extract (SIE) on the antioxidant defense system in cadmium chloride-exposed common carp, a species with a high value of culture in the world. Heavy metals, particularly, cadmium have been found as the main source of aquatic pollution and have been detected in alarming quantities in many water environments, especially at or near industrial localities where effluents are usually discharged (Chandra and Khuda-Bukhsh, 2004). The findings of the present study suggest a possible natural way to ameliorate the deleterious effects caused by cadmium in fish.

\section{Material and methods}

\section{Preparation of herbal extract}

The silymarin in dry form was provided from a local medicinal plants shop. The extraction was done based on the method suggested by Hajirezaee et al. (2019) by a rotary (Buchi, Switzerland) at $80^{\circ} \mathrm{C}$. The concentrated extract was finally dried at $40^{\circ} \mathrm{C}$ to make powder. The powders were eventually kept at $0^{\circ} \mathrm{C}$ till the beginning of the experiment.

\section{Fish and experimental design}

Common carp ( $\mathrm{n}=1650 ; \mathrm{TW}: 22.1 \pm 4.1 \mathrm{~g}$; TL: $11.8 \pm 2.2 \mathrm{~cm})$ were distributed into 15 tanks (500 1) (110 fish per tank) containing aerated and disinfected water. After a 10-day acclimation period, fish were divided into four groups in three replicates within 30 tanks containing $100 \mathrm{~L}$ continually aerated water and fed for 60 days with various dietary levels of silymarin extract (SIE). The dietary treatments were: $\mathrm{SIE}_{0}$ (control): non-supplemented fish, SIE $: 400 \mathrm{mg} \mathrm{SIE} / \mathrm{kg}$ diet, SIE $: 1400 \mathrm{mg} \mathrm{SIE} / \mathrm{kg}$ diet, $\mathrm{SIE}_{3}: 2400 \mathrm{mg} \mathrm{SIE} / \mathrm{kg}$ diet. A commercial basal diet (pellet, crude protein: $36 \%$, crude lipid: 6\%, carbohydrates: $12 \%$, crude fiber: $4 \%$, ash: $9 \%$, Faradaneh Company, Iran) was used to make experimental diets. In this regard, the basal diet was powdered by a mill, and then the dried extracts (SIE) were added to the diet at a rate of $0 \mathrm{mg}, 400 \mathrm{mg}, 1400 \mathrm{mg}$, and $2400 \mathrm{mg} / \mathrm{kg}$ diet. After complete mixing, the mixture became paste by adding 100 $\mathrm{ml}$ of distilled water. Then, the appropriate size of food (as granule; diameter: $3 \pm 0.1 \mathrm{~mm}$, length: $3.5 \pm 0.2 \mathrm{~mm}$ ) was made using a sieve. Then, the foods were respectively kept at room temperature (away from light) and in an oven $\left(\right.$ at $30^{\circ} \mathrm{C}$ ) to dry. Finally, the foods were stored in a refrigerator $\left(4^{\circ} \mathrm{C}\right)$ (Nya and Austin, 2009). Feeding operation was performed daily and at a rate of $3 \%$ total fish weight. The amount of needed food was regulated at intervals of 10 days by estimating total fish weight. After 60 days feeding trial, fish were exposed to $1.5 \mathrm{mg} / 1$ cadmium chloride (Merck Co., Germany, CAS number: 35658-65-2) for $96 \mathrm{~h}$. The exposure concentration was calculated based on $25 \%(1.5 \mathrm{mg} / \mathrm{l})$ of LC50-96 h (6 $\mathrm{mg} / \mathrm{l})$. The amount of $\mathrm{LC}_{50}$ was determined in a previous separate experiment. In this regard, fish with a density of 10 per 10-liter aquarium were exposed to different doses of cadmium chloride in three replications, including: 0.5 , 1, 1.5, 2, 2.5, 3, 3.5, 4, 4.5, 5, 5.5, 6, 6.5, 7, 7.5, $8 \mathrm{mg} / \mathrm{l}$. Finally, the concentration, which yielded $50 \%$ mortality over $96 \mathrm{~h}$, was determined as the amount of $\mathrm{LC}_{50}$.

Throughout the experiment, the water quality properties were $\mathrm{pH}$ : $6.8 \pm 0.1$ (APX15/C-WTW-330i), temperature: $22.5 \pm 1.2^{\circ} \mathrm{C}$, ammonia: $0.02 \pm 0.002 \mathrm{mg} / \mathrm{L}$ (colorimetrically at $670 \mathrm{~nm}$ ) and dissolved oxygen: $7.2 \pm 0.15$ $\mathrm{mg} / \mathrm{L}$ (OxyGouard). Also, the numbers of dead fish were recorded during the experiment to estimate mortality percent. In addition, the growth parameters, including final weight, final weight gain, specific growth rate and feed conversion ratio (FCR), were determined after the feeding trial according to following formula:

$$
\begin{gathered}
\text { Feed conversion ratio }(F C R)=\text { Dry weight of feed } \\
\text { given }(g) \text { /weight gain }(g) \\
\text { Specific growth rate }=\left(\ln w_{f^{-}} \ln w_{0} T\right) \times 100
\end{gathered}
$$

where: $\mathrm{w}_{\mathrm{f}}$ : final weight, $\mathrm{w}_{0}$ : initial weight.

\section{Blood and liver sampling}

The blood and liver samples were collected after 60 days feeding trial. The blood sampling was done $6 \mathrm{~h}$ after last feeding. For this purpose, fish were anesthetized with clove oil (100 mg/l) (Malekpouri et al., 2011) and the blood samples were taken from the caudal fin by $2 \mathrm{ml} \mathrm{sy-}$ ringe (10 fish/tank). The plasma samples were obtained through centrifuging at $13,700 \mathrm{~g}$ for $10 \mathrm{~min}$. Plasma samples were then frozen in liquid nitrogen $\left(-196^{\circ} \mathrm{C}\right)$ till further assays. Besides, liver tissue samples were taken after dissecting out the fish and then kept in liquid nitrogen $\left(-196^{\circ} \mathrm{C}\right)$ for further assays.

\section{Biochemical assays of plasma}

All assays were conducted according to manufacturer's instructions.

LDH levels were measured at $450 \mathrm{~nm}$ based on the oxidation rate of NADH (Sigma-Aldrich Co., USA, catalogue number: MAK066).

CK activity was assayed at $340 \mathrm{~nm}$ by measuring the amount of phosphate transferred from phosphocreatine to ADP during phosphorylation of glucose (Sigma-Aldrich Co., USA, catalogue number: MAK116). 
AST levels were measured at $450 \mathrm{~nm}$ by calculating the deamination rate of aspartate to a-ketoglutarate and the following generation of glutamate (at $37^{\circ} \mathrm{C}, \mathrm{pH}$ : 8.0 ) (Sigma-Aldrich Co., USA, catalogue number: MAK055).

ALT levels were assayed at $570 \mathrm{~nm}$ based on the production rate of pyruvate (Sigma-Aldrich Co., USA, catalogue number: MAK052).

ALP activity was measured at $405 \mathrm{~nm}$ by estimating the conversion rate of $\mathrm{p}$-nitrophenol phosphate to nitrophenol (Sigma-Aldrich Co., USA, catalogue number: GTX85593).

\section{Biochemical assays of liver}

The total antioxidant capacity (TAC) was assayed using the ferric reducing ability of plasma (FRAP) method, according to Benzie and Strain (1996). Briefly, the liver tissues were homogenized in cooled phosphate buffer $(\mathrm{pH} 7.4)$ in the ratio of $1: 10(\mathrm{w} / \mathrm{v})$ and then centrifuged (15 min; $13700 \mathrm{~g}$, at $4^{\circ} \mathrm{C}$ ) to separate the supernatant. After that, a $0.01 \mu \mathrm{l}$ of the supernatant sample was poured into $0.3 \mathrm{ml}$ FRAP reagent, and the absorbance was read at $593 \mathrm{~nm}$.

Catalase (CAT) activity was assayed at $240 \mathrm{~nm}$ based on the production of water and oxygen from catalysis of hydrogen peroxide $\left(\mathrm{H}_{2} \mathrm{O}_{2}\right)$ (Sigma-Aldrich Co., USA, catalogue number: CAT100) (Claiborne, 2018).

Superoxide dismutase (SOD) activity was determined colourimetrically at $440 \mathrm{~nm}$ through oxidation of xanthine to superoxide radicals (SOR) and further reaction of SOR with WST-1 reagent to create a red formazan dye (Marklund and Marklund, 1974) (Sigma-Aldrich Co., USA, catalogue number: 19160 SOD).

Glutathione peroxidase (GPX) levels were determined at $340 \mathrm{~nm}$ based on the generation of oxidized glutathione from glutathione (GSH) upon GPx action (Sigma-Aldrich Co., USA, catalogue number: CGP1).

Liver acetylcholinesterase (AChE) activity was also measured at $412 \mathrm{~nm}$ according to an optimized method of Ellman et al. (1961). In this assay, thiocholine is generated from acetylthiocholine iodide $(0.015 \mathrm{M})$ as a result of $\mathrm{AChE}$ action and then the produced thiocholine reacts with Ellman's reagent $(0.01 \mathrm{M})$ to generate a dye product (Sigma-Aldrich Co., USA, catalogue number: MAK119).

The lipid peroxidation was spectrophotometrically (at $532 \mathrm{~nm}$ ) determined upon reaction of malondialdehyde (MDA) with thiobarbituric acid and following production of a dye product (Utley et al., 1967) (Sigma-Aldrich Co., USA, catalogue number: MAK085).

\section{Statistical analysis}

All statistical analysis was performed using SPSS software. After the normality of data (mean \pm standard deviation) was verified and confirmed, one-way analysis of variance was used to detect statistical differences. Finally, the difference between the means was determined using the Tukey test. The percent data were converted by arcsin transformation before ANOVA.

\section{Results}

\section{Biochemicals after feeding trial}

The supplementation of fish with $1400-2400 \mathrm{mg} / \mathrm{kg}$ diet SIE significantly increased TAC levels compared to control and those supplemented with $400 \mathrm{mg} / \mathrm{kg}$ diet SIE (Figure 1, $\mathrm{P}<0.01$ ). The MDA (Figure 2, $\mathrm{P}>0.01$ ) and AChE (Figure 3, $\mathrm{P}>0.01$ ) levels remained unchanged during the feeding period in all experimental groups $(\mathrm{P}>0.01)$. The levels of antioxidants, SOD (Figure $4 \mathrm{a}$, $\mathrm{P}<0.01$ ) and GPx (Figure $4 \mathrm{~b}, \mathrm{P}<0.01$ ), significantly increased in the fish supplemented with $1400-2400 \mathrm{mg} / \mathrm{kg}$ diet SIE. There were no significant differences in SOD (Figure $4 \mathrm{a}, \mathrm{P}>0.01$ ) and GPx (Figure $4 \mathrm{~b}, \mathrm{P}>0.01$ ) levels between control and fish fed $400 \mathrm{mg} / \mathrm{kg}$ diet SIE. The levels of CAT were elevated in all SIE supplemented fish compared to control (Figure $4 \mathrm{c}, \mathrm{P}<0.01$ ). The metabolic enzymes of liver, ALT (Figure 5 a), AST (Figure 5 b), ALP (Figure 5 c), CK (Figure 5 d), LDH (Figure 5 e) remained unchanged in all experimental groups after 60 days feeding period $(\mathrm{P}>0.01)$.

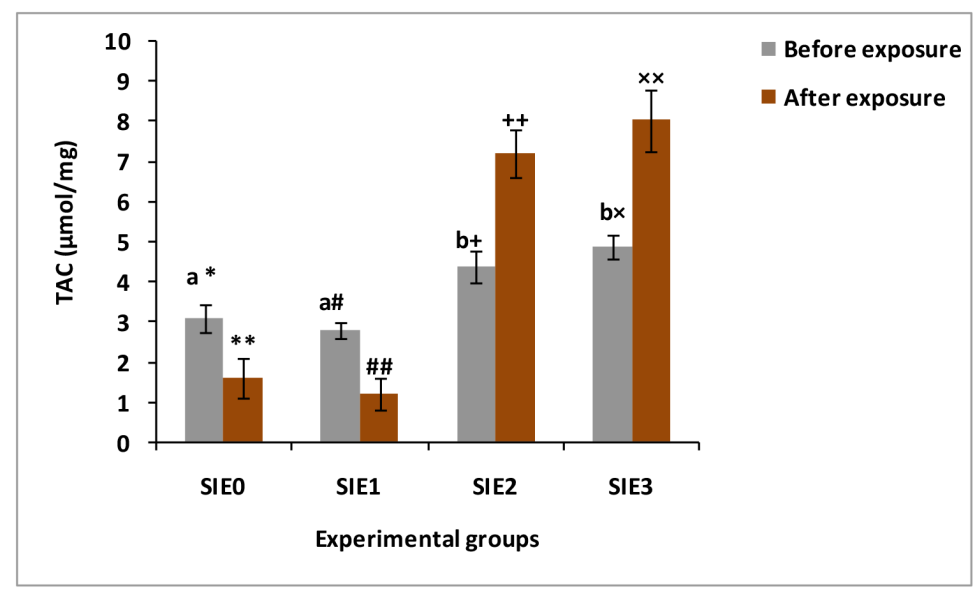

Figure 1. Effects of silymarin extract (SIE) supplementation on the liver TAC (total antioxidant capacity) activity before and after exposure to cadmium chloride in common carp. SIE (control): non-supplemented fish, SIE: $400 \mathrm{mg} \mathrm{SIE} / \mathrm{kg} \mathrm{diet,} \mathrm{SIE}_{2}: 1400 \mathrm{mg} \mathrm{SIE} / \mathrm{kg}$ diet, SIE $: 2400$ $\mathrm{mg} \mathrm{SIE} / \mathrm{kg}$ diet. Significant differences are shown with different letters $(\mathrm{P}<0.01)$. For each group, significant differences between "before" and "after" exposure is shown as different symbols $(\mathrm{P}<0.01)$ 


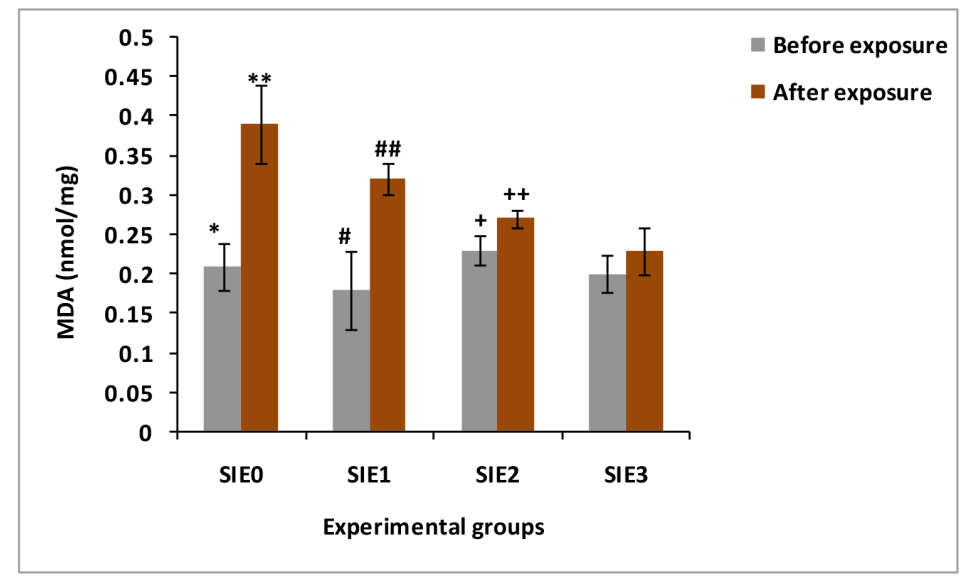

Figure 2. Effects of silymarin extract (SIE) supplementation on the liver MDA levels (malondialdehyde) before and after exposure to cadmium chloride in common carp. $\mathrm{SIE}_{0}$ (control): non-supplemented fish, $\mathrm{SIE}_{1}: 400 \mathrm{mg} \mathrm{SIE} / \mathrm{kg}$ diet, $\mathrm{SIE}_{2}: 1400 \mathrm{mg} \mathrm{SIE} / \mathrm{kg}$ diet, $\mathrm{SIE}_{3}: 2400 \mathrm{mg} \mathrm{SIE} /$ $\mathrm{kg}$ diet. Significant differences are shown with different letters $(\mathrm{P}<0.01)$. For each group, significant differences between "before" and "after" exposure is shown as different symbols $(\mathrm{P}<0.01)$

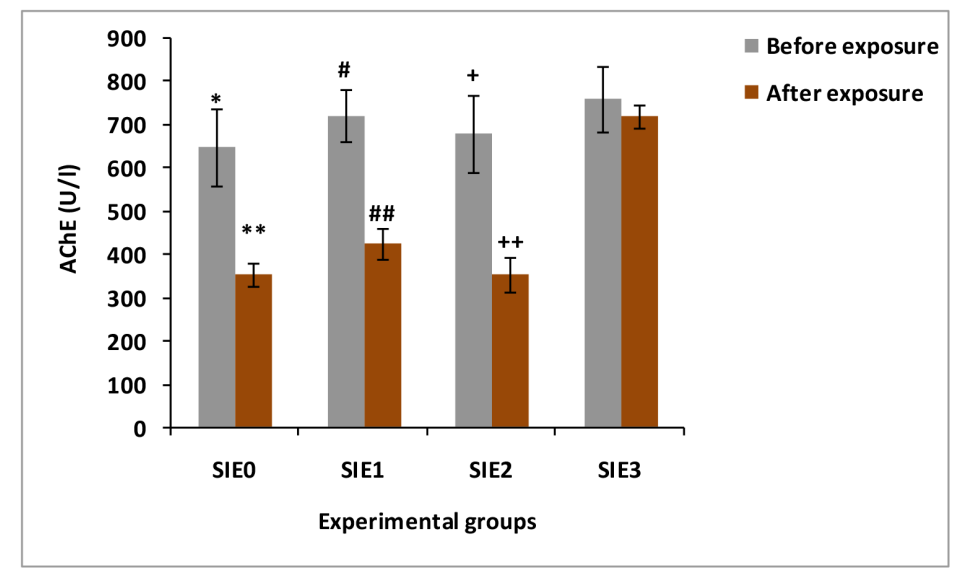

Figure 3. Effects of silymarin extract (SIE) supplementation on the liver AChE levels (acetylcholinesterase) before and after exposure to cadmium chloride in common carp. $\mathrm{SIE}_{0}$ (control): non-supplemented fish, $\mathrm{SIE}_{1}: 400 \mathrm{mg} \mathrm{SIE} / \mathrm{kg}$ diet, $\mathrm{SIE}_{2}: 1400 \mathrm{mg} \mathrm{SIE} / \mathrm{kg}$ diet, $\mathrm{SIE}_{3}: 2400$ $\mathrm{mg} \mathrm{SIE} / \mathrm{kg}$ diet. Significant differences are shown with different letters $(\mathrm{P}<0.01)$. For each group, significant differences between "before" and "after" exposure is shown as different symbols $(\mathrm{P}<0.01)$

Biochemicals after exposure to cadmium chloride After exposure to cadmium chloride, TAC levels significantly increased in fish supplemented with 1400 and $2400 \mathrm{mg} \mathrm{SIE} / \mathrm{kg}$ diet (Figure 1, $\mathrm{P}<0.01$ ). Fish of control and those supplemented with $400 \mathrm{mg} \mathrm{SIE} / \mathrm{kg}$ diet decreased after exposure (Figure 1, $\mathrm{P}<0.01$ ). The MDA levels were significantly elevated in control and fish fed 400 and $1400 \mathrm{mg} \mathrm{SIE} / \mathrm{kg}$ diet (Figure 2, $\mathrm{P}<0.01$ ). The fish fed $2400 \mathrm{mg} \mathrm{SIE} / \mathrm{kg}$ diet showed no significant changes after exposure (Figure 2, $\mathrm{P}>0.01$ ). The antioxidant enzymes, CAT (Figure $4 \mathrm{c}, \mathrm{P}<0.01$ ), SOD (Figure $4 \mathrm{a}, \mathrm{P}<0.01$ ) and GPx (Figure 4 b, $P<0.01$ ) significantly increased in response to cadmium chloride in all groups. The treatments 1400 and $2400 \mathrm{mg} \mathrm{SIE} / \mathrm{kg}$ diet showed lower increases in antioxidant enzymes after exposure compared to other groups (Figure 4 a, b, c, $\mathrm{P}<0.01$ ). The liver $\mathrm{AChE}$ ac- tivity (Figure 3, $\mathrm{P}<0.01$ ) significantly declined in control and fish fed 400 and $1400 \mathrm{mg} \mathrm{SIE} / \mathrm{kg} \operatorname{diet}(\mathrm{P}<0.01)$. The exposure to cadmium significantly increased the plasma levels of ALT (Figure 5 a), AST (Figure 5 b), ALP (Figure $5 \mathrm{c}$ ), LDH (Figure 5 e) in control and those supplemented with 400 and $1400 \mathrm{mg} \mathrm{SIE} / \mathrm{kg}$ diet $(\mathrm{P}<0.01)$.

\section{Growth performance and survival rate}

The growth parameters including final weight, final weight gain, FCR and survival rate showed no significant difference between all groups after 60 days feeding trial (Table 1, $\mathrm{P}>0.01$ ). After exposure to cadmium chloride, the survival rate significantly decreased in control and $400 \mathrm{mg} \mathrm{SIE} / \mathrm{kg}$ diet treatment compared to $400-2400 \mathrm{mg}$ $\mathrm{SIE} / \mathrm{kg}$ diet treatments (Figure 6, $\mathrm{P}<0.01$ ). 

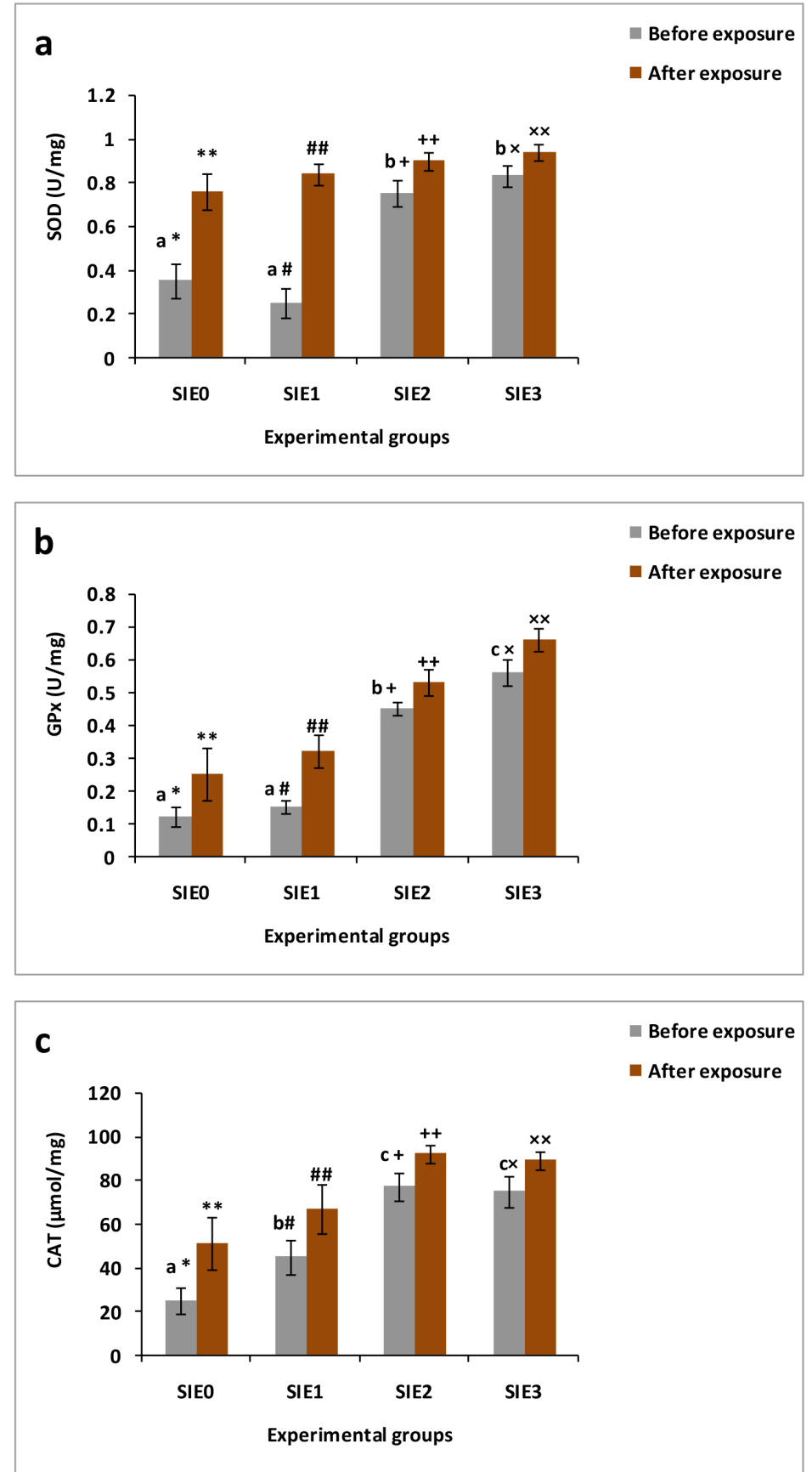

Figure 4. Effects of silymarin extract (SIE) supplementation on the liver antioxidant enzymes [SOD (superoxide dismutase) (plot a); GPx

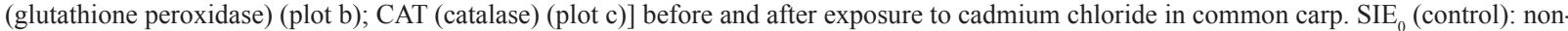
supplemented fish, $\mathrm{SIE}_{1}: 400 \mathrm{mg} \mathrm{SIE} / \mathrm{kg}$ diet, $\mathrm{SIE}_{2}: 1400 \mathrm{mg} \mathrm{SIE} / \mathrm{kg}$ diet, $\mathrm{SIE}_{3}: 2400 \mathrm{mg} \mathrm{SIE} / \mathrm{kg}$ diet. Significant differences are shown with different letters $(\mathrm{P}<0.01)$. For each group, significant differences between "before" and "after" exposure is shown as different symbols $(\mathrm{P}<0.01)$

Table 1. The growth parameter changes of common carp during 60 days feeding with diet containing various levels of silymarin extract (SIE). $\mathrm{SIE}_{0}$ (control): non-SIE-supplemented fish, $\mathrm{SIE}_{1}: 400 \mathrm{mg} \mathrm{SIE} / \mathrm{kg}$ diet, $\mathrm{SIE}_{2}: 1400 \mathrm{mg} \mathrm{SIE} / \mathrm{kg}$ diet, $\mathrm{SIE}_{3}: 2400 \mathrm{mg} \mathrm{SIE} / \mathrm{kg}$ diet. Significant differences are shown with different letters $(\mathrm{P}<0.01)$

\begin{tabular}{|c|c|c|c|c|}
\hline \multirow{2}{*}{ Growth parameters } & \multicolumn{4}{|c|}{ Treatments } \\
\hline & $\operatorname{SIE}_{0}$ (control) & $\mathrm{SIE}_{1}$ & $\mathrm{SIE}_{2}$ & $\mathrm{SIE}_{3}$ \\
\hline Initial weight (g) & $23.2 \pm 4.5$ & $21.8 \pm 3.3$ & $22.6 \pm 4.8$ & $24.3 \pm 5.5$ \\
\hline Final weight (g) & $125.6 \pm 10.2$ & $130.9 \pm 12.5$ & $128.1 \pm 15.5$ & $130.5 \pm 13.3$ \\
\hline Final weight gain $(\%)$ & $441.3 \pm 126.6$ & $500.4 \pm 278.7$ & $466.8 \pm 222.9$ & $437.1 \pm 141.8$ \\
\hline Specific growth rate & $4.89 \pm 1.02$ & $5.21 \pm 1.2$ & $5.05 \pm 1.06$ & $4.81 \pm 1.1$ \\
\hline FCR & $1.25 \pm 0.06$ & $1.21 \pm 0.05$ & $1.24 \pm 0.07$ & $1.22 \pm 0.08$ \\
\hline
\end{tabular}



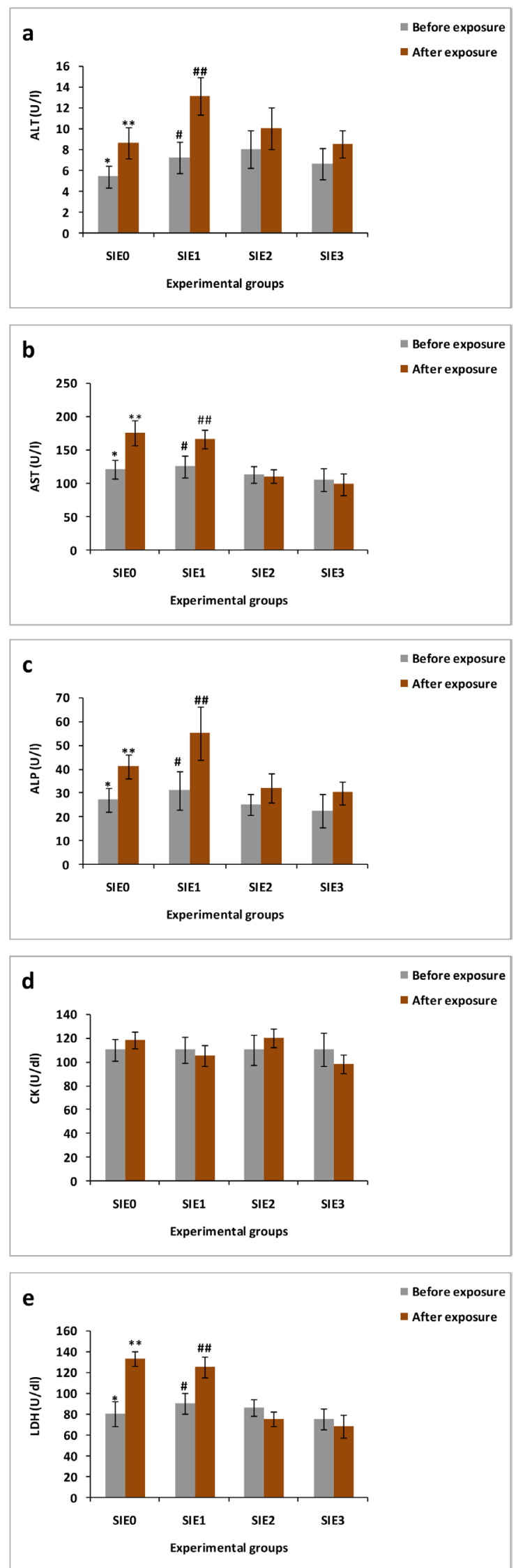

Figure 5. Effects of silymarin extract (SIE) supplementation on the plasma levels of hepatic metabolic enzymes [ALT (alanine transaminase) (plot a), AST (aspartate aminotransferase) (plot b), ALP (alkaline phosphatase) (plot c), CK (creatine kinase) (plot d), LDH (lactate dehydrogenase) (plot e)] before and after exposure to cadmium chloride in common carp. SIE (control): non-supplemented fish, $\mathrm{SIE}_{1}: 400 \mathrm{mg} \mathrm{SIE} / \mathrm{kg}$ diet, $\mathrm{SIE}_{2}: 1400 \mathrm{mg} \mathrm{SIE} / \mathrm{kg}$ diet, $\mathrm{SIE}_{3}: 2400 \mathrm{mg} \mathrm{SIE} / \mathrm{kg}$ diet. Significant differences are shown with different letters $(\mathrm{P}<0.01)$. For each group, significant differences between "before and "after" exposure is shown as different symbols $(\mathrm{P}<0.01)$ 


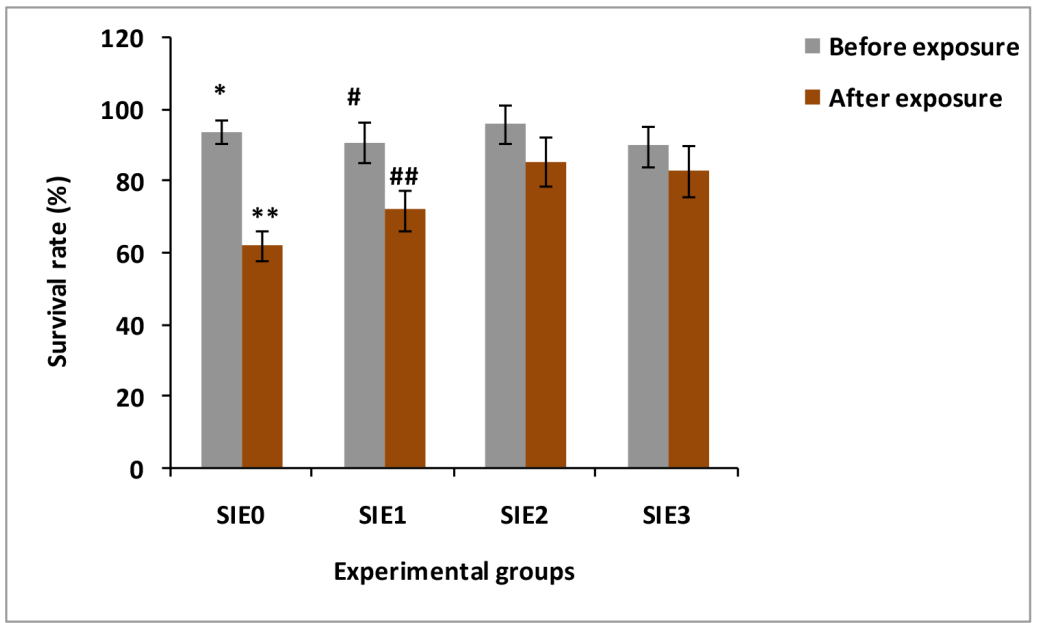

Figure 6. Effects of silymarin extract (SIE) supplementation on the survival rate before and after exposure to cadmium chloride in common carp. $\mathrm{SIE}_{0}$ (control): non-supplemented fish, SIE $: 400 \mathrm{mg} \mathrm{SIE} / \mathrm{kg}$ diet, $\mathrm{SIE}_{2}: 1400 \mathrm{mg} \mathrm{SIE} / \mathrm{kg}$ diet, SIE $: 2400 \mathrm{mg}$ SIE $/ \mathrm{kg}$ diet. Significant differences are shown with different letters $(\mathrm{P}<0.01)$. For each group, significant differences between "before" and "after" exposure is shown as different symbols $(\mathrm{P}<0.01)$

\section{Discussion}

The use of immunostimulants has considerably increased in aquaculture to improve fish growth, immunity, and survival (Bricknell and Dalmo, 2005; Ringø et al., 2012; Ahmadifar et al., 2020). Among immunostimulants, special attention has been paid to natural components as an alternative to chemicals (Van Hai, 2015; Mohammadi et al., 2020). In this respect, many studies have focused on medicinal plants (MEPs) and their effects on fish and shellfish (Dügenci et al., 2003; Jian and Wu, 2004; Citarasu et al., 2006; Ardó et al., 2008; Aly and Mohamed, 2010; Abdel-Tawwab, 2010; Choi et al., 2014; Güroy et al., 2014). Although the immunostimulant properties of MEPs have been largely reported, little data is available related to the protective role of them against toxicity caused by heavy metals in fish (Banaee et al., 2015 b; Rabie et al., 2016).

In the present study, GPX, SOD and CAT showed higher activities in SIE supplemented fish, particularly in 1400 and $2400 \mathrm{mg} \mathrm{SIE} / \mathrm{kg}$ diet treatments compared to control. These results demonstrated that silymarin at optimized dietary levels could improve the hepatic antioxidative abilities of common carp, as TAC also increased in SIE supplemented fish. The enhancing effects of silymarin on hepatic antioxidant enzymes have been previously documented in fish and other vertebrates (Jia et al., 2013; Wang et al., 2019; Veisi et al., 2021).

SOD is responsible for removal of superoxide radicals (Kohen and Nyska, 2002). CAT exerts its antioxidant function by removing hydrogen peroxide radicals (Van der Oost et al., 2003). Furthermore, GSH-Px catalyzes hydrogen peroxide radicals to water and also eliminates lipid peroxide radicals by converting them to lipid alcohols. During this process, glutathione is oxidized to glutathione disulfide as a consequence of GSH-Px action.
After exposure to cadmium chloride, the antioxidant enzymes were significantly elevated in all groups, which may be an antioxidant response to reduce the oxidative stress induced by the heavy metal, as previously reported in other exposed fish (Almeida et al., 2002; Basha and Rani, 2003). In this study, MDA levels were significantly elevated in control and fish fed 400 and $1400 \mathrm{mg} \mathrm{SIE} /$ $\mathrm{kg}$ diet after exposure, indicating cadmium chloride-inducing oxidative stress in the fish. In biological systems, MDA is well known as the main indicator of oxidative stress (Janero, 1990; Dragun et al., 2017). In contrast to control and 400-1400 mg SIE/kg treatments, fish supplemented with 1400 and $2400 \mathrm{mg} \mathrm{SIE} / \mathrm{kg}$ diet showed lower increases of the antioxidant enzymes, indicating the ameliorating effects of SIE supplementation on hepatic antioxidant defense system. The protective effects of silymarin may be related to antioxidative properties of this plant and thus its potentials in scavenging the free radicals and sparing the levels of antioxidant enzymes in 1400 and $2400 \mathrm{mg} \mathrm{SIE} / \mathrm{kg}$ diet treatments. The composition of silymarin includes some components with free radical-scavenging and antioxidant activity such as taxifolin, silychristin, silydianin, silybin B, iso-silybin A and iso-silybin B (Anthony and Saleh, 2013). Taxifolin is known as the most effective component for scavenging free radicals (Anthony and Saleh, 2013).

The plasma levels of liver metabolic enzymes are usually used as biomarkers of hepatic damages (Ghelichpour et al., 2017). An elevation in plasma levels of these enzymes is usually attributed to liver tissue damages and following release of them into the circulatory system. However, these enzymes are non-specific, and their levels may fluctuate in response to other factors such as diseases. In this study, the exposure to cadmium chloride significantly increased the plasma levels of ALT, ALP, AST and LDH in control and those fed diet containing 400 and $1400 \mathrm{mg}$ SIE. This result may be a consequence 
of the toxic effects of cadmium chloride on hepatocytes and following release of these enzymes to bloodstream (Vaglio and Landriscina, 1999; Heydarnejad et al., 2013; Al-Asgah et al., 2015; Atli et al., 2015).

In $2400 \mathrm{mg} \mathrm{SIE} / \mathrm{kg}$ treatment, although the plasma levels of AST, ALP, ALT and LDH were elevated after exposure, these increases were lower compared to other groups. These results clearly show that SIE at a concentration of $2400 \mathrm{mg} / \mathrm{kg}$ diet protects the hepatocytes against cadmium chloride-induced tissue damages.

AChE is responsible for inactivating the neurotransmitter acetylcholine and identified as a specific indicator of PC toxicity (Khan and Law, 2005; Deb and Das, 2017). Any disruptions in AChE activity results in the accumulation of acetylcholine and following blockage of signal transmission (Fulton and Key, 2001). Disruptions in swimming pattern, feeding and reproductive behaviour have been reported as consequences of signal transmission disrupted by acetylcholine (Pavlov et al., 1992; dos Santos Miron et al., 2005; Kavitha and Rao, 2008). After exposure to cadmium chloride, the liver AChE activity was significantly reduced in control and fish supplemented with 400 and $1400 \mathrm{mg} \mathrm{SIE} / \mathrm{kg}$, indicating the depressing effects of cadmium on AChE activity, as reported in other studies (Gill et al., 1991; Sen et al., 1995; Pretto et al., 2010; Banaee et al., 2015 b; Zhang et al., 2017). In $2400 \mathrm{mg} \mathrm{SIE} / \mathrm{kg}$ diet treatment, AChE activity remained unchanged after exposure, which apparently indicates the ameliorating effects of SIE at optimized concentration on cadmium chloride-related depressions of $\mathrm{AChE}$ activity.

\section{Conclusion}

The findings of the present study suggested a protective role for silymarin extract at optimized dietary levels against toxic effects caused by cadmium chloride. Silymarin at optimized dietary levels (1400-2400 mg/ $\mathrm{kg}$ diet) improved the antioxidant system and survival in cadmium chloride-exposed common carp. Identification of compounds with detoxifying effects in the chemical composition of silymarin and study of their mechanism of action can be suggested for future studies.

\section{Conflict of interest statement}

There is no conflict of interest to declare.

\section{Ethical approval}

All applicable international, national, and/or institutional guidelines for the care and use of animals were followed.

\section{References}

Abdel-Tawwab M., Ahmad M.H., Seden M.E., Sakr S.F. (2010). Use of green tea, Camellia sinensis L., in practical diet for growth and protection of Nile tilapia, Oreochromis niloticus (L.), against Aeromonas hydrophila infection. J. World Aquacult. Soc., 41(s2): 203-213.
Ahmadifar E., Yousefi M., Karimi M., Fadaei Raieni R., Dadar M., Yilmaz S., Dawood M.A., Abdel-Latif H.M. (2020). Benefits of dietary polyphenols and polyphenol-rich additives to aquatic animal health: an overview. Rev. Fish. Sci., 1-34.

Ahmadifar E., Kalhor N., Dawood M.A., Ahmadifar M., Shahriari Moghadam M., Yousefi M. (2021). Effects of dietary p-coumaric acid on the growth performance, digestive enzyme activity, humoral immunity and immune-related gene expression in common carp, Cyprinus carpio. Aquacult. Nutr., 27: 747-756.

Al-Asgah N.A., Abdel-Warith A.W.A., Younis E.S.M., Allam H.Y. (2015). Haematological and biochemical parameters and tissue accumulations of cadmium in Oreochromis niloticus exposed to various concentrations of cadmium chloride. Saudi J. Biol. Sci., 22: 543-550.

Alishahi M., Soltani M., Mesbah M., Rad A.E. (2011). Effects of dietary Silybum marianum extract on immune parameters of the common carp (Cyprinus carpio). J. Vet. Res., 66: 255-286.

Almeida J.A., Diniz Y.S., Marques S.F.G., Faine L.A., Ribas B.O., Burneiko R.C., Novelli E.L.B. (2002). The use of the oxidative stress responses as biomarkers in Nile tilapia (Oreochromis niloticus) exposed to in vivo cadmium contamination. Environ. Int., 27: 673-679.

Aly S.A., Mohamed M.F. (2010). Echinacea purpurea and Allium sativum as immunostimulants in fish culture using Nile tilapia (Oreochromis niloticus). J. Anim. Physiol. Anim. Nutr., 94: e31-e39.

Ansari T.M., Marr I.L., Tariq N. (2004). Heavy metals in marine pollution perspective-a mini review. J. Appl. Sci., 4: 1-20.

Anthony K.P., Saleh M.A. (2013). Free radical scavenging and antioxidant activities of silymarin components. Antioxidants., 2: 398-407.

Ardó L., Yin G., Xu P., Váradi L., Szigeti G., Jeney Z., Jeney G. (2008). Chinese herbs (Astragalus membranaceus and Lonicera japonica) and boron enhance the non-specific immune response of Nile tilapia (Oreochromis niloticus) and resistance against Aeromonas hydrophila. Aquaculture, 275: 26-33.

Atli G., Ariyurek S.Y., Kanak E.G., Canli M. (2015). Alterations in the serum biomarkers belonging to different metabolic systems of fish (Oreochromis niloticus) after $\mathrm{Cd}$ and $\mathrm{Pb}$ exposures. Environ. Toxicol. Pharmacol., 40: 508-515.

Banaee M., Sureda A., Shahaf S., Fazilat N. (2015 a). Protective effects of silymarin extract on malthion-induced zebra cichlid (Cichlasoma nigrofasciatum) hepatotoxicity. Iran. J. Toxicol., 9: 1239-1246.

Banaee M., Mehrpak M., Hagi B.B.N., Noori A. (2015 b). Amelioration of cadmium-induced changes in biochemical parameters of the muscle of common carp (Cyprinus carpio) by vitamin $\mathrm{C}$ and chitosan. Int. J. Aquat. Biol., 3: 362-371.

Basha P.S., Rani A.U. (2003). Cadmium-induced antioxidant defense mechanism in freshwater teleost Oreochromis mossambicus (Tilapia). Ecotoxicol. Environ. Saf., 56: 218-221.

Benzie I.F., Strain J.J. (1996). The ferric reducing ability of plasma (FRAP) as a measure of "antioxidant power": the FRAP assay. Analytic. Biochem., 239: 70-76

Bhuyan M.S., Islam M.S. (2017). A critical review of heavy metal pollution and its effects in Bangladesh. Sci. J. Energy Eng., 5: 95-108.

Bricknell I., Dalmo R.A. (2005). The use of immunostimulants in fish larval aquaculture. Fish Shellfish Immunol., 19: 457-472.

Chandra P., Khuda-Bukhsh A.R. (2004). Genotoxic effects of cadmium chloride and azadirachtin treated singly and in combination in fish. Ecotoxicol. Environ. Saf., 58: 194-201.

Choi W.M., Mo W.Y., Wu S.C., Mak N.K., Bian Z.X., Nie X.P., Wong, M.H. (2014). Effects of traditional Chinese medicines (TCM) on the immune response of grass carp (Ctenopharyngodon idella). Aquacult. Int., 22: 361-377.

Chowdhury S., Saikia S.K. (2020). Oxidative stress in fish: a review. J. Sci. Res., 12: 145-160.

Chupani L., Zusková E., Niksirat H., Panáček A., Lünsmann V., Haange S.B., von Bergen M., Jehmlich N. (2017). Effects of chronic dietary exposure of zinc oxide nanoparticles on the serum protein profile of juvenile common carp (Cyprinus carpio L.). Sci. Total Environ., 579: 1504-1511.

Chupani L., Niksirat H., Velíšek J., Stará A., Hradilová Š., Kolařík J., 
Panáček A., Zusková E. (2018). Chronic dietary toxicity of zinc oxide nanoparticles in common carp (Cyprinus carpio L.): tissue accumulation and physiological responses. Ecotoxicol. Environ. Saf., 147: 110-116.

Citarasu T., Sivaram V., Immanuel G., Rout N., Murugan V. (2006). Influence of selected Indian immunostimulant herbs against white spot syndrome virus (WSSV) infection in black tiger shrimp, Penaeus monodon with reference to haematological, biochemical and immunological changes. Fish Shellish Immunol., 21: $372-384$.

Claiborne A.L. (2018). Catalase activity. In CRC handbook of methods in oxygen radical research. CRC Press, pp. 283-284.

Dawood M.A., Abdel-Tawwab M., Abdel-Latif H.M. (2020). Lycopene reduces the impacts of aquatic environmental pollutants and physical stressors in fish. Rev. Aquac., 12: 2511-2526.

Deb N., Das S. (2017). Chlorpyrifos toxicity in fish: A Review. Curr. World Environ., 8: 77-84.

Dos Santos Miron D., Crestani M., Shettinger M.R., Morsch V.M., Baldisserotto B., Tierno M. A., Moraes G., Vieira V.L.P. (2005). Effects of the herbicides clomazone, quinclorac, and metsulfuron methyl on acetylcholinesterase activity in the silver catfish (Rhamdia quelen) (Heptapteridae). Ecotoxicol. Environ. Saf., 61: $398-403$.

Dragun Z., Marijić V.F., Krasnići N., Ramani S., Valić D., Rebok K., Kostov V., Jordanova M., Erk M. (2017). Malondialdehyde concentrations in the intestine and gills of Vardar chub (Squalius vardarensis Karaman) as indicator of lipid peroxidation. Environ. Sci. Pollut. Res., 24: 16917-16926.

Dügenci S.K., Arda N., Candan A. (2003). Some medicinal plants as immunostimulant for fish. J. Ethnopharmacol., 88: 99-106.

Ebrahimi M., Taherianfard M. (2011). The effects of heavy metals exposure on reproductive systems of cyprinid fish from Kor River. Iran. J. Fish. Sci., 10: 13-26.

Ellman G.L., Courtney, K.D., Andres Jr V., Featherstone R.M. (1961). A new and rapid colorimetric determination of acetylcholinesterase activity. Biochem. Pharmacol, 7: 88-95.

Elumalai P., Kurian A., Lakshmi S., Faggio C., Esteban M.A., Ringe E. (2020). Herbal immunomodulators in aquaculture. Rev. Fish. Sci., 1-25.

Fulton M.H., Key P.B. (2001). Acetylcholinesterase inhibition in estuarine fish and invertebrates as an indicator of organophosphorus insecticide exposure and effects. Environ. Toxicol. Chem., 20: $37-45$.

Ghelichpour M., Taheri Mirghaed A., Mirzargar S.S., Joshaghani H., Ebrahimzadeh Mousavi H. (2017). Plasma proteins, hepatic enzymes, thyroid hormones and liver histopathology of Cyprinus carpio (Linnaeus, 1758) exposed to an oxadiazin pesticide, indoxacarb. Aquacult. Res., 48: 5666-5676.

Gill T.S., Tewari H., Pande J. (1991). In vivo and in vitro effects of cadmium on selected enzymes in different organs of the fish Barbus conchonius Ham. (Rosy barb). Comp. Biochem. Physiol. C Toxicol. Pharmacol., 100: 501-505.

Guardiola F.A., Dioguardi M., Parisi M.G., Trapani M.R., Meseguer J., Cuesta A., Cammarata M., Esteban M.A. (2015). Evaluation of waterborne exposure to heavy metals in innate immune defences present on skin mucus of gilthead seabream (Sparus aurata). Fish Shellfish Immunol., 45: 112-123.

Güroy B., Mantoğlu S., Kayalı S., Sahin İ. (2014). Effect of dietary Yucca schidigera extract on growth, total ammonia-nitrogen excretion and haematological parameters of juvenile striped catfish Pangasianodon hypophthalmus. Aquacult. Res., 45: 647654.

Hajirezaee S., Rafieepour A., Shafiei S., Rahimi R. (2019). Immunostimulating effects of Ginkgo biloba extract against toxicity induced by organophosphate pesticide, diazinon in rainbow trout, Oncorhynchus mykiss: innate immunity components and immunerelated genes. Environ. Sci. Pollut. Res., 26: 8798-8807.

Hajirezaee S., Ajdari A., Azhang B. (2021). Metabolite profiling, histological and oxidative stress responses in the grey mullet, Mugil cephalus exposed to the environmentally relevant concentrations of the heavy metal, $\mathrm{Pb}(\mathrm{NO} 3)$ 2. Comp. Biochem. Physiol. C Toxicol. Pharmacol., 244: 109004.
Heydarnejad M.S., Khosravian-Hemamai M., Nematollahi A. (2013). Effects of cadmium at sub-lethal concentration on growth and biochemical parameters in rainbow trout (Oncorhynchus mykiss). Ir. Vet. J., 66: 1-7.

Janero D.R. (1990). Malondialdehyde and thiobarbituric acid-reactivity as diagnostic indices of lipid peroxidation and peroxidative tissue injury. Free Radical Biol. Med., 9: 515-540.

Jia R., Cao L., Du J., Xu P., Jeney G., Yin G. (2013). The protective effect of silymarin on the carbon tetrachloride $\left(\mathrm{CCl}_{4}\right)$-induced liver injury in common carp (Cyprinus carpio). In Vitro Cell. Dev. Biol. Animal., 49: 155-161.

Jian J., Wu Z. (2004). Influences of traditional Chinese medicine on non-specific immunity of Jian carp (Cyprinus carpio var. Jian). Fish Shellfish Immunol., 16: 185-191.

Jinhui S., Sudong X., Yan N., Xia P., Jiahao Q., Yongjian X. (2019). Effects of microplastics and attached heavy metals on growth, immunity, and heavy metal accumulation in the yellow seahorse, Hippocampus kuda Bleeker. Mar. Pollut. Bull., 149: 110510.

Joksimović D., Perošević A., Castelli A., Pestorić B., Šuković, D., Đurović D. (2020). Assessment of heavy metal pollution in surface sediments of the Montenegrin coast: a 10-year review. J. Soils Sediments., 20: 2598-2607.

Kavitha P., Rao J.V. (2008). Toxic effects of chlorpyrifos on antioxidant enzymes and target enzyme acetylcholinesterase interaction in mosquito fish, Gambusia affinis. Environ. Toxicol. Pharmacol., 26: 192-198.

Khafaga A.F., Naiel M.A., Dawood M.A., Abdel-Latif H.M. (2020). Dietary Origanum vulgare essential oil attenuates cypermethrininduced biochemical changes, oxidative stress, histopathological alterations, apoptosis, and reduces DNA damage in Common carp (Cyprinus carpio). Aquat. Toxicol., 228: 105624.

Khan M.Z., Law F.C. (2005). Adverse effects of pesticides and related chemicals on enzyme and hormone systems of fish, amphibians and reptiles: a review. Proc. Pak. Acad. Sci., 42: 315-323.

Kohen R., Nyska A. (2002). Invited review: Oxidation of biological systems: oxidative stress phenomena, antioxidants, redox reactions, and methods for their quantification. Toxicol. Pathol., 30: $620-650$.

Křen V., Walterová D. (2005). Silybin and silymarin - new effects and applications. Biomed. Pap., 149: 29-41.

Kvasnička F., Biba B., Ševčík R., Voldřich M., Kratka, J. (2003). Analysis of the active components of silymarin. J. Chromatogr. A., 990: 239-245.

Malekpouri P., Moshtaghie A.A., Kazemian M., Soltani M. (2011). Protective effect of zinc on related parameters to bone metabolism in common carp fish (Cyprinus carpio L.) intoxified with cadmium. Fish Physiol. Biochem., 37: 187-196.

Marklund S., Marklund G. (1974). Involvement of the superoxide anion radical in the autoxidation of pyrogallol and a convenient assay for superoxide dismutase. FEBS J., 47: 469-474.

Miskowiec P., Laptas A., Zieba K. (2015). Soil pollution with heavy metals in industrial and agricultural areas: a case study of Olkusz District. J. Elem., 20: 353-362.

Mohammadi G., Rafiee G., El Basuini M.F., Van Doan H., Ahmed H.A., Dawood M.A., Abdel-Latif H.M. (2020). Oregano (Origanum vulgare), St John's-wort (Hypericum perforatum), and lemon balm (Melissa officinalis) extracts improved the growth rate, antioxidative, and immunological responses in Nile tilapia (Oreochromis niloticus) infected with Aeromonas hydrophila. Aquac. Rep., 18: 100445.

Mohammed E., Kamel M., El Iraqi K., Tawfik A.M., Khattab M.S., Elsabagh, M. (2020). Zingiber officinale and Glycyrrhiza glabra, individually or in combination, reduce heavy metal accumulation and improve growth performance and immune status in Nile tilapia, Oreochromis niloticus. Aquacult. Res., 51: 1933-1941.

Nazdar N., Imani A., Noori F., Moghanlou K. S. (2018). Effect of silymarin supplementation on nickel oxide nanoparticle toxicity to rainbow trout (Oncorhynchus mykiss) fingerlings: pancreas tissue histopathology and alkaline protease activity. Iran. J. Sci. Technol. Trans. A: Sci., 42: 353-361.

Nya E. J., Austin B. (2009). Use of dietary ginger, Zingiber officinale Roscoe, as an immunostimulant to control Aeromonas hydrophila 
infections in common carp, Cyprinus carpio (Walbaum). J. Fish Dis., 32: 971-977.

Pavlov D.D., Chuiko G.M., Gerassimov Y.V., Tonkopiy V. D. (1992). Feeding behavior and brain acetylcholinesterase activity in bream (Abramis brama L.) as affected by DDVP, an organophosphorus insecticide. Comp. Biochem. Physiol. C Toxicol Pharmacol., 103: $563-568$.

Pretto A., Loro V.L., Morsch V.M., Moraes, B.S., Menezes C., Clasen B., Hoehne L., Dressler V. (2010). Acetylcholinesterase activity, lipid peroxidation, and bioaccumulation in silver catfish (Rhamdia quelen) exposed to cadmium. Arch. Environ. Contam. Toxicol., 58: 1008-1014.

Rabie M., Asri Y., Ahmadi K. (2016). Effect of milk thistle plant, Vitis vinifera extract on immune system of common carp (Oncorhynchus mykiss) challenge by diazinon. Int. J. Aquat. Biol., 4: 208214.

Rafieepour A., Hajirezaee S., Rahimi R. (2019 a). Dietary oregano extract (Origanum vulgare L.) enhances the antioxidant defence in rainbow trout, Oncorhynchus mykiss against toxicity induced by organophosphorus pesticide, diazinon. Toxin Rev., 39: 397-407.

Rafieepour A., Hajirezaee S., Rahimi R. (2019 b). Moderating effects of dietary oregano extract (Origanum vulgare) on the toxicity induced by organophosphate pesticide, diazinon in rainbow trout, Oncorhynchus mykiss: metabolic hormones, histology and growth parameters. Turk. J. Fish. Aquat. Sci., 20: 207-219.

Ringø E., Olsen R.E., Vecino J.G., Wadsworth S., Song S.K. (2012), Use of immunostimulants and nucleotides in aquaculture: a review. J. Mar. Sci.: Res. Dev., 2: 104.

Saglam D., Atli G., Canli M. (2013). Investigations on the osmoregulation of freshwater fish (Oreochromis niloticus) following exposures to metals $(\mathrm{Cd}, \mathrm{Cu})$ in differing hardness. Ecotoxicol. Environ. Saf., 92: 79-86.

Sen S., Mondal S., Adhikari J., Sarkar D., Bose S., Mukhopadhyay B., Bhattacharya S. (1995). Inhibition of fish brain acetylcholinesterase by cadmium and mercury. In: Enzymes of the cholinesterase family. Springer, Boston, MA., pp. 369-374.

Sodango T.H., Li X., Sha J., Bao Z. (2018). Review of the spatial distribution, source and extent of heavy metal pollution of soil in China: impacts and mitigation approaches. J. Health. Pollut., 8: 53-70.
Tahar K., Keltoum B. (2011). Effects of heavy metals pollution in soil and plant in the industrial area, West Algeria. J. Korean Chem. Soc., 55: 1018-1023.

Utley H.G., Bernheim F., Hochstein P. (1967). Effect of sulfhydryl reagents on peroxidation in microsomes. Arch. Biochem. Biophys., 118: 29-32.

Vaglio A., Landriscina C. (1999). Changes in liver enzyme activity in the Teleost Sparus aurata in response to cadmium intoxication. Ecotoxicol. Environ. Saf., 43: 111-116.

Van der Oost R., Beyer J., Vermeulen N.P. (2003). Fish bioaccumulation and biomarkers in environmental risk assessment: a review. Environ. Toxicol. Pharmacol., 13: 57-149.

Van Hai N. (2015). The use of medicinal plants as immunostimulants in aquaculture: a review. Aquaculture, 446: 88-96.

Veisi S., Johari S.A., Tyler C.R., Mansouri, B., Esmaeilbeigi M. (2021). Antioxidant properties of dietary supplements of free and nanoencapsulated silymarin and their ameliorative effects on silver nanoparticles induced oxidative stress in Nile tilapia (Oreochromis niloticus). Environ. Sci. Pollut. Res., 22: 1-9.

Wang J., Zhou H., Wang X., Mai K., He G. (2019). Effects of silymarin on growth performance, antioxidant capacity and immune response in turbot (Scophthalmus maximus L.). J. World Aquacult. Soc., 50: 1168-1181.

Yang Q., Li Z., Lu X., Duan Q., Huang L., Bi J. (2018). A review of soil heavy metal pollution from industrial and agricultural regions in China: Pollution and risk assessment. Sci. Total Environ., 642: 690-700.

Yousafzai A.M., Shakoori A.R. (2011). Hepatic responses of a freshwater fish against aquatic pollution. Pak. J. Zool., 43: 209-221.

Zhang T., Yang M., Pan H., Li S., Ren B., Ren Z., Xing N., Qi L., Ren Q., Xu S. Song J. (2017). Does time difference of the acetylcholinesterase (AChE) inhibition in different tissues exist? A case study of zebra fish (Danio rerio) exposed to cadmium chloride and Deltamethrin. Chemosphere, 168: 908-916.

Zhu F. (2020). A review on the application of herbal medicines in the disease control of aquatic animals. Aquaculture, 28: 735422.

Received: 25 III 2021

Accepted: 6 VIII 2021 